\title{
Article \\ Changes of Soil Organic Carbon after Wildfire in a Boreal Forest, Northeast CHINA
}

\author{
Chun-Lan Han ${ }^{1}$, Zhong-Xiu Sun ${ }^{1, *}$, Shuai Shao ${ }^{1}$, Qiu-Bing Wang ${ }^{1, *}$, Zamir Libohova ${ }^{2}$ and Phillip Ray Owens ${ }^{2}$ \\ 1 College of Land and Environment, Shenyang Agricultural University, Shenyang 110866, China; \\ hancly@syau.edu.cn (C.-L.H.); shuaishao2019@zafu.edu.cn (S.S.) \\ 2 Dale Bumpers Small Farms Research Center, United States Department of Agriculture, Booneville, AR 72927, USA; \\ zamir.libohova@usda.gov (Z.L.); Phillip.Owens@usda.gov (P.R.O.) \\ * Correspondence: zhongxiusun@syau.edu.cn (Z.-X.S.); qbwang@syau.edu.cn (Q.-B.W.); \\ Tel.: +86-157-3400-5989 (Z.-X.S.)
}

check for

updates

Citation: Han, C.-L.; Sun, Z.-X.; Shao, S.; Wang, Q.-B.; Libohova, Z.; Owens, P.R. Changes of Soil Organic Carbon after Wildfire in a Boreal Forest, Northeast CHINA. Agronomy 2021, 11, 1925. https://doi.org/10.3390/ agronomy11101925

Academic Editors: Long Guo, Xiaodong Song, Abdul M. Mouazen and Peng Fu

Received: 22 August 2021

Accepted: 18 September 2021

Published: 25 September 2021

Publisher's Note: MDPI stays neutral with regard to jurisdictional claims in published maps and institutional affiliations.

Copyright: (c) 2021 by the authors. Licensee MDPI, Basel, Switzerland. This article is an open access article distributed under the terms and conditions of the Creative Commons Attribution (CC BY) license (https:/ / creativecommons.org/licenses/by/ $4.0 /)$.
Abstract: Boreal forests with high carbon sequestration capacity play a crucial role in mitigating global climate change. Addressing dynamic changes of soil organic carbon (SOC) after wildfire helps in understanding carbon cycling. The objective of this study is to investigate changes in soil organic carbon after wildfires in a boreal forest. The post-fire soil chronosequence after 3 months, 17 years, and 25 years within a boreal forest was used to examine dynamic and stable SOC after wildfire at the decadal scale. Soils in genetic horizons were sampled and analyzed for dynamic and stable SOC, including water stable aggregates (WSA), WSA associated organic carbon (WSA-SOC), soil heavy fractions (HF) associated organic carbon (HF-SOC), and soil total organic carbon (TOC). The TOC and WSA-SOC content of the A horizon was the greatest in the control site. There was no significant difference for TOC between burned and unburned deep BC horizons. The TOC for the A and B horizons at the 17-year-old site was significantly lower compared to the other sites. TOC did not recover to the pre-fire levels (control site) in any of the burned areas. The lowest WSA was found in the A and B horizons of the 3-month-old site. The WSA at the 25-year-old site was higher compared to the 17-year-old site. WSA increased with time following fire, but the recovery rate differed among different sites. The lowest concentration of WSA-SOC for the A horizon occurred at the 17-year-old site, and no significant difference was observed between $\mathrm{B}$ and $\mathrm{BC}$ horizons. The HF content for the A horizon was the greatest at the 3-month-old site. There was no significant difference in HF-SOC between B and BC horizons in all sites. TOC and stable SOC (HF and WSA) increased over time in species-dominance relay stand areas, while self-replacement stands areas showed the opposite. The results indicate that overall, the ability of soil to sequester carbon decreased after wildfire disturbances. Stable SOC accumulated more in areas where species-dominance relay succession occurred compared to the self-replacement stands. These disturbances were more pronounced for surface soil horizons. This study provides a quantitative assessment of SOC changes after wildfires that are useful for forest management and modeling forecasts of SOC stocks, especially in boreal forests.

Keywords: post-fire soil chronosequence; soil organic carbon (SOC); SOC stocks; wildfire effects

\section{Introduction}

Boreal forest soils play an important role in the global carbon cycle. The amount of carbon stored in forests soils is controlled by the carbon input from vegetation leaves and roots, and by soils, which can store vast quantities of organic carbon [1,2]. Boreal forests show high soil organic carbon (SOC) sequestration due to their large woody biomass, extensive roots, and abundant leaf litter, while the mineralization rate of organic carbon is relatively slow due to poor drainage and low temperatures [3,4]. Boreal forests are important to alleviate global warming by preferentially increasing the fungal mineralization of slow-turnover carbon pools in boreal organic soils [5]. Boreal forest can also be a significant contributor to the atmospheric $\mathrm{CO}_{2}$ from above and underground biomass 
burning [6]. A recent review [7] points to the importance of underground biomass burning (smoldering) as a significant contributor to atmospheric $\mathrm{CO}_{2}$.

Analyzing post-fire succession is important to understand boreal forest dynamics and how it affects SOC. Forest fires change the composition of species in the local ecosystem $[8,9]$ and affect the establishment and development of wooded areas across landscapes [10]. In the Greater Higgnan Mountains region, tree regeneration after wildfires has two major ecological succession pathways; self-replacement and species-dominance relay. Self-replacement is the condition under which dominant tree species of pre-fire canopy that was burned by a fire naturally recovers as the dominant canopy species. In contrast, species-dominance relay occurs when different tree species successively assume canopy dominance following fire [11]. Both successional pathways are important for the development of forest composition and influence the potential response of boreal forests to future disturbances and climate change. Generally, burned areas in the Greater Higgnan Mountains region develop into secondary succession after severe fire disturbance [12]. The succession type depends on whether there is a birch (Betula platyphylla) invasion. If the habitat conditions are suitable for a birch invasion, community succession occurs. Then larch (Larix gmelinii) forests develop to replace birch tree species until larch forest formation reaches a climax. If birch seeds do not spread to fire-affected areas, only single larch forest self-replacement will occur after severe fire disturbance in the Greater Higgnan Mountains region [12]. During re-vegetation and plant succession, carbon accumulates both in the biomass and the soil $[13,14]$. After a wildfire, reforestation accelerates the conversion of the fire-affected areas from carbon source to carbon sink [15], although natural regeneration may also increase carbon sequestration [16].

SOC stabilization includes chemical stabilization, biochemical stabilization, and physical protection. The accumulation of SOC due to physical protection is a result of the influence of aggregation in the formation of fracture planes (the sides of aggregates connected by cementing agents), which act as barriers to microbial action [17]. Soil aggregates are important agents in SOC retention and protection from decomposition [18,19]. The soil aggregation process and aggregate stability are affected by land management and disturbances [20,21]. Soil aggregates have been reported to increase with re-vegetation in a landslide area [22] and nitrogen fertilization in prairie regions [23]. However, studies on the effects of fire on soil aggregates in forests have shown opposite results [24,25]. Mataix-Solera et al. suggested that the effects of fire on soil aggregation depend on fire intensity and its influence on aggregation-related properties such as soil organic matter, water repellency, mineral compositions, and soil microorganisms [24]. The soil light fractions' (LF) and soil heavy fractions' (HF) associated organic carbon (LF-SOC and HF-SOC), was determined using the density fractionation method as described by Gregorich and Ellert (1993).They are useful to identify specific carbon pools and evaluate their responses to soil management strategies which involve controlling SOC [26] and characterizing soil quality for sustainable land use [27]. Heavy fractions (HF) are more stable and contain greater processed SOC [28,29], while high-density organo-mineral fractions have lower carbon concentrations [30]. HF is a major carbon sink [31] that can lead to poor soil respiration [32]. Both soil stable carbon fractions are indicative of soil capability to sequester carbon.

The objective of this study is to investigate changes in soil organic carbon after wildfires in Larix gmelinii forests. TOC and soil stable carbon fractions, aggregate-associated organic carbon (WSA-SOC), and heavy fraction organic carbon (HF-SOC) were determined both in the surface and the subsurface horizons. We hypothesized that the SOC pool and its physical fraction following wildfires decreased due to the combustion of soil organic matter, and that SOC levels would begin to recover following re-vegetation through stand development. 


\section{Materials and Methods}

\subsection{The Study Area}

The study area is located in the Greater Higgnan Mountains region, northeastern China $\left(\mathrm{N} 50^{\circ} 10^{\prime} \sim 53^{\circ} 33^{\prime}, \mathrm{E} 121^{\circ} 12^{\prime} \sim 127^{\circ} 00^{\prime}\right)$. It covers an area of 84,600 ha [33]. This region belongs to the cold temperate zone and has a cool continental climate with hot-wet summer and cold-snowy winter. The mean annual temperature and precipitation are $-4{ }^{\circ} \mathrm{C}$ and $400-500 \mathrm{~mm}$, respectively. The dry spring and high winds promote conditions for forest fires. The dominant tree species in the study area is Larix gmelinii, while other prevalent tree species are Pinus sylvestris var mongolica, Picea koraiensis, Betula platyphylla, Quercus mongolica, and Populus davidiana. Shrubs include Rhododendron dauricum, Vaccinium vitisidaea, Ledum palustre, and Lespedeza bicolor. The parent material in the study area is primarily igneous rock resulting in igneous residuum soils or soil formed from igneous rock colluvium. The predominant soils can be classified as Cambisols according to the Keys to Chinese Soil Taxonomy (3rd edition) [34] and World Reference Base [35], and Inceptisols according to the US Soil Taxonomy [36].

The Greater Higgnan Mountains region is the worst-hit area from forest fires in China. During the 1970 to 2006 period, forest fires occurred on average 27.8 times a year with an annual average burned forest cover area of $7.5 \times 10^{4}$ ha. Three types of causes of fires were identified: lightning, human-caused, and unknown [37], typically occurring between April and June. Since the 1990s, the annual amount of forest fires has shown an increasing trend, affected most likely by a combination of increased global temperatures and human activities, including accidental fires [33,38].

\subsection{Soil Sampling}

Three independent sites were sampled that had experienced high-intensity fires at different times ( 3 months prior, 17 years prior, and 25 years prior) and have a similar soil genesis history all occurring within the Greater Higgnan Mountains region. After wildfires, soils on both plant succession types of species dominant relay (the larch forest was replaced by an early-seral community of small-leaved trees) and self-replacement (the larch forest replaces itself rapidly) were sampled. The soil in an area where no records of fire occurred for over 30 years was selected as the background control (Table 1). Fire intensity was estimated by comparing remote sensing images before and after fire using the Composite Burn Index (CBI) records [39]. To minimize the effects of site conditions, especially erosion, on SOC and stable SOC, areas on flat slopes of less than $3^{\circ}$ were selected. The soils have developed from igneous rock and are described as well-drained and greater than $50 \mathrm{~cm}$ in thickness, are the most dominant site type of this area. Each selected region had similar soil-topographic characteristics. Soil profiles were excavated in the center of each plot. A square plot of $20 \mathrm{~m} \times 20 \mathrm{~m}$ was selected within each region and three random soil profiles were excavated in each square plot. Soils were described and sampled according to the standard procedures described in the "Field Book for Describing and Sampling Soils, version 3.0" [40].

\subsection{Soil Analysis}

Soil samples were air-dried in the laboratory and the moisture content of samples was determined by the oven-dry method $\left(105^{\circ} \mathrm{C}\right.$ for $\left.12 \mathrm{~h}\right)$. Stones and plant roots were removed with a $2 \mathrm{~mm}$ sieve. Mineral soil samples were ground in an agate mortar and sieved in a $0.149 \mathrm{~mm}$ sieve. 
Table 1. General conditions of the studied sites.

\begin{tabular}{|c|c|c|c|c|c|c|c|c|c|c|c|c|}
\hline Sample Type & Locations & $\begin{array}{l}\text { Predominant } \\
\text { Tree Type }\end{array}$ & $\begin{array}{l}\text { Predominant } \\
\text { Shrub Type }\end{array}$ & $\begin{array}{l}\text { Canopy } \\
\text { Density }\end{array}$ & $\begin{array}{c}\text { Shrub } \\
\text { Height (m) }\end{array}$ & $\begin{array}{c}\text { Shrub } \\
\text { Coverage (\%) }\end{array}$ & $\begin{array}{l}\text { Herb } \\
\text { Height } \\
\text { (cm) }\end{array}$ & $\begin{array}{c}\text { Herb } \\
\text { Coverage (\%) }\end{array}$ & $\begin{array}{l}\text { Altitude } \\
\text { (m) }\end{array}$ & $\begin{array}{l}\text { Successional } \\
\text { Types }\end{array}$ & $\begin{array}{c}\text { Soil } \\
\text { Taxonomy } \\
\text { Reference }\end{array}$ & $\begin{array}{c}\text { Year of } \\
\text { Forest Fire }\end{array}$ \\
\hline 25-year-old & $\begin{array}{c}\text { Xi lin ji Forestry } \\
\text { Bureau }\end{array}$ & $\begin{array}{c}\text { Betula } \\
\text { platyphylla. }\end{array}$ & Ledum spp. & 0.7 & 2 & 35 & 50 & 80 & 565 & $\begin{array}{l}\text { Species- } \\
\text { dominance } \\
\text { relay }\end{array}$ & Cambisols & 1987 \\
\hline 17-year-old & $\begin{array}{l}\text { Han jia yuan } \\
\text { ForestryBureau }\end{array}$ & Larix gmelinii. & Carex sp. & 0.2 & 0.6 & 80 & 60 & 10 & 286 & Self-replacement & Cambisols & 1995 \\
\hline 3-month-old & $\begin{array}{c}\text { Xi lin ji Forestry } \\
\text { Bureau }\end{array}$ & Larix gmelinii. & Ledum spp. & 0.4 & 0.3 & 70 & 40 & 20 & 550 & Undifferentiated & Cambisols & 2012 \\
\hline Control & $\begin{array}{c}\text { Ta he Forestry } \\
\text { Bureau }\end{array}$ & Larix gmelinii. & $\begin{array}{l}\text { Rhododendron } \\
\text { dauricum }\end{array}$ & 0.5 & 0.8 & 8 & 20 & 55 & 419 & & Cambisols & No fire \\
\hline
\end{tabular}




\subsubsection{Water Stable Aggregates (WSA) Associated SOC (WSA-SOC)}

The size distribution of the water stable aggregates (WSA) was measured by wet sieving [41] with a soil aggregate analyzer (DM200 Shanghai, China). A $100 \mathrm{~g}$ sample of airdried bulk soil (passed through a $6.75 \mathrm{~mm}$ sieve) was placed on top of a set of nested sieves $(2000,250$, and $53 \mu \mathrm{m})$ [18]. Nested sieves were placed in a bucket that was slowly filled with deionized water (poured along the edge to minimize disturbance) until the uppermost sieve touched the water. Aggregates were slowly wet through capillary action over $30 \mathrm{~min}$ time intervals. After being submerged for $5 \mathrm{~min}$ at room temperature, the nested sieves were gently oscillated ( $5 \mathrm{~cm}$ amplitude and 25 strokes $\mathrm{min}^{-1}$ ) within a column of water for $30 \mathrm{~min}$. Following, different sized WSA were gently backwashed off the sieve into an aluminum pan. Floating organic material $(>2 \mathrm{~mm}$ ) was removed and discarded because large organic material is not considered as soil organic matter. Aggregates were oven-dried $\left(60^{\circ} \mathrm{C}\right)$ to constant moisture content, weighed, and stored in glass jars at room temperature. WSA were classified into macro $(>2.0 \mathrm{~mm}$ and $0.25 \sim 2.0 \mathrm{~mm})$ and micro $(0.053 \sim 0.25 \mathrm{~mm}$ and $<0.053 \mathrm{~mm}$ ) size classes, and relative abundance was expressed as dry weight to the total sample (100 g). The WSA-SOC concentration in each fraction of $>2000 \mu \mathrm{m}, 250-2000 \mu \mathrm{m}$, 53-250 $\mu \mathrm{m}$, and $<53 \mu \mathrm{m}$ were measured, respectively.

Water stable aggregates (WSA) were calculated as follows [17]:

$$
\text { WSA }=\frac{\sum_{i=1}^{n} w i}{w} \times 100 \%
$$

where WSA = water stable aggregates $(\%)$, wi $=$ weight of the aggregate fraction, $\mathrm{w}=$ total weight of sample used. Soil aggregates were classified into macro (>2000 $\mu \mathrm{m}$ and 250 2000 $\mu \mathrm{m}$ ) and micro $(53 \sim 250 \mu \mathrm{m}$ and $<53 \mu \mathrm{m})$ size classes, and their relative abundance in each category was expressed as a percentage of the total sample.

The WSA-SOC content $(\mathrm{g}$ ) was calculated as the WSA-SOC concentration multiply by the weight of each size fraction of WSA.

\subsubsection{Density Fractionation of $S O C$}

Soil heavy fractions (HF) were determined using the density fractionation method as described by Gregorich and Ellert [42]. In brief, air-dried soil (5 g) was placed in a $50 \mathrm{~mL}$ conical centrifuge tube with $35 \mathrm{~mL} \mathrm{NaI}$ solution $\left(1.7 \mathrm{~g} \mathrm{~cm}^{-3}\right)$ and gently stirred with a glass rod. Samples were ultrasonicated at $250 \mathrm{~W}$ for $20 \mathrm{~min}$ with a KQ-250E sonicator (Kunshan Ultrasonic Instrument Company, China), then filtered through a $0.45 \mu \mathrm{m}$ filter. The light fractions (LF) retained on the filter were rinsed with $100 \mathrm{~mL} 0.01 \mathrm{M} \mathrm{CaCl}_{2}$ and then with $200 \mathrm{~mL}$ deionized water to remove the $\mathrm{NaI}$ and $\mathrm{CaCl}_{2}$. Sediment from the centrifuge tubes was re-suspended in $\mathrm{NaI}$ by gently stirring with a glass rod. The procedure was repeated twice. The three sub-fractions were combined and oven-dried at $50{ }^{\circ} \mathrm{C}$ for the LF. The HF were rinsed twice with $100 \mathrm{~mL}$ deionized water, and the remaining soil after rinsing was dried at $50{ }^{\circ} \mathrm{C}$ for $8 \mathrm{~h}$ and weighed [43]. The HF-SOC concentration in the $\mathrm{HF}$ fraction was subsequently measured. The HF-SOC content (g) was calculated as the HF-SOC concentration multiply by the weight of HF.

\subsubsection{Chemical and SOC Sample Analysis}

The $\mathrm{pH}\left(\mathrm{H}_{2} \mathrm{O}\right)$ and $\mathrm{pH}(\mathrm{KCl})$ were determined by the 1:2.5 ratio of soil to water or the saturated $\mathrm{KCl}$ solution. The soil total-nitrogen $(\mathrm{N})$ and soil total organic carbon of mineral soil samples TOC, WSA-SOC, and HF-SOC were determined by the dry combustion method using an Elemantar Vario III (Elementar, https: / www.elementar.com/ (accessed on 17 August 2021)). 


\subsection{Statistical Analysis}

The difference among TOC concentrations, abundance of WSA, WSA-SOC, and HFSOC in mineral horizons was analyzed using a one-way analysis of variance. Data was analyzed using Sigmaplot 12.5 and SPSS 13.0.

\section{Results}

\subsection{The Soil Properties}

Wildfires profoundly influenced the development and succession of the forest ecosystem. Species-dominance relay succession occurred at the 25-year-old site (25 years after fire disturbance), where deciduous trees (especially Betula platyphylla) had colonized the area. Self-replacement succession occurred at the 17-year-old site (17 years after fire disturbance), where Larix gmelinii dominated. The type of vegetation after wildfire clearly influenced canopy density ranging from 0.2 to 0.7 (Table 1 ).

The basic characterization of mineral soil with depth is provided in Table 2. Dry samples were mostly yellow-orange or pinkish-white in color, while wet samples were brown, dark brown or yellow-brown. The texture of surface layers was loam and silt loam, while the sub-surface horizons were primarily clay loam and sandy loam. The soil structure was granular in A horizon at all sites except for the 3month-old site, where the structure was more blocky than granular (Table 2). The B and BC horizons were described as having a blocky structure. The bulk density of the surface soil from the fires was, on average, smaller than control. The $\mathrm{pH}\left(\mathrm{H}_{2} \mathrm{O}\right)$ and $\mathrm{pH}(\mathrm{KCl})$ of horizons in the soil profiles after wildfire was higher compared to the control, and the levels at the 17-year-old site were significantly greater than that of the 25-year-old site. The total-nitrogen $(\mathrm{N})$ level was greatest in the control site, and the 25-year-old site had a greater $\mathrm{N}$ level than that of the 17-year-old site.

Table 2. Morphological characteristics of mineral horizons in the studied sites.

\begin{tabular}{|c|c|c|c|c|c|c|c|c|c|c|c|c|}
\hline \multirow{2}{*}{$\begin{array}{l}\text { Sample } \\
\text { Type }\end{array}$} & \multirow{2}{*}{$\begin{array}{c}\text { Soil } \\
\text { Horizon }\end{array}$} & \multirow{2}{*}{$\begin{array}{c}\text { Depth } \\
\text { (Amiro et al.) }\end{array}$} & \multicolumn{2}{|c|}{ Soil Color } & \multirow{2}{*}{$\begin{array}{c}\text { Soil } \\
\text { Texture }\end{array}$} & \multirow{2}{*}{ Soil Structure } & \multirow{2}{*}{ Roots } & \multirow{2}{*}{$\begin{array}{c}\text { Bulk } \\
\text { Density } \\
\left(\mathrm{g} \mathrm{cm}^{-3}\right)\end{array}$} & \multirow{2}{*}{$\begin{array}{l}\text { Gravel } \\
(\%)\end{array}$} & \multirow{2}{*}{$\mathrm{pH}\left(\mathrm{H}_{2} \mathrm{O}\right)$} & \multirow{2}{*}{$\mathrm{pH}(\mathrm{KCl})$} & \multirow{2}{*}{$\underset{\left(\mathrm{g} \mathrm{kg}^{-1}\right)}{\mathrm{T}}$} \\
\hline & & & Dry & Wet & & & & & & & & \\
\hline \multirow{3}{*}{ Control } & Ah & $0-10$ & 10YR 7/4 & $10 Y R 4 / 6$ & Loam & Small granular & $\begin{array}{l}\text { Few medium roots, } \\
\text { moderate fine roots }\end{array}$ & 0.85 & 0 & $4.50 \pm 0.06$ & $3.48 \pm 0.04$ & $2.62 \pm 0.43$ \\
\hline & Bw & $10-61$ & $2.5 Y 8 / 4$ & 10 YR $5 / 4$ & Clay loam & Small blocky & $\begin{array}{l}\text { Very few medium and } \\
\text { few fine roots }\end{array}$ & 1.48 & 45 & $4.50 \pm 0.04$ & $3.56 \pm 0.02$ & $1.37 \pm 0.2$ \\
\hline & $\mathrm{BC}$ & 61-104 & $2.5 Y 8 / 4$ & $10 \mathrm{YR} 5 / 6$ & $\begin{array}{l}\text { Sandy } \\
\text { loam }\end{array}$ & Medium blocky & Very few fine roots & 1.61 & 70 & $5.48 \pm 0.12$ & $3.64 \pm 0.02$ & $1.24 \pm 0.12$ \\
\hline \multirow{3}{*}{ 25-year-old } & Ah & $0-10$ & 10YR 8/1 & $10 \mathrm{YR} 4 / 2$ & Loam & Small granular & $\begin{array}{l}\text { Very few medium } \\
\text { roots and few fine } \\
\text { roots }\end{array}$ & 1.20 & 0 & $4.68 \pm 0.07$ & $3.46 \pm 0.04$ & $2.02 \pm 0.34$ \\
\hline & $\begin{array}{l}\text { Bts1 } \\
\text { Bts2 }\end{array}$ & $\begin{array}{l}10-38 \\
38-82\end{array}$ & $\begin{array}{l}\text { 7.5YR } 8 / 3 \\
10 Y R 6 / 3\end{array}$ & $\begin{array}{l}10 \mathrm{YR} 5 / 4 \\
10 \mathrm{YR} 5 / 3\end{array}$ & $\begin{array}{l}\text { Clay loam } \\
\text { Clay loam }\end{array}$ & $\begin{array}{l}\text { Medium platy } \\
\text { Small blocky }\end{array}$ & $\begin{array}{l}\text { Few fine roots } \\
\text { Few fine roots }\end{array}$ & $\begin{array}{l}1.55 \\
1.47\end{array}$ & $\begin{array}{c}0 \\
10\end{array}$ & $\begin{array}{l}4.92 \pm 0.26 \\
5.40 \pm 0.18\end{array}$ & $\begin{array}{l}3.68 \pm 0.07 \\
3.90 \pm 0.02\end{array}$ & $\begin{array}{c}1.25 \pm 0.12 \\
1.21 \pm 0.1\end{array}$ \\
\hline & $\mathrm{BC}$ & $82-100$ & 10YR $6 / 3$ & $10 \mathrm{YR} 3 / 3$ & $\begin{array}{l}\text { Sandy } \\
\text { loam }\end{array}$ & Medium blocky & A few of fine roots & 1.60 & 23 & $5.58 \pm 0.04$ & $4.18 \pm 0.02$ & $1.06 \pm 0.12$ \\
\hline \multirow{2}{*}{ 17-year-old } & $\mathrm{Ah}$ & $0-17$ & 10YR $8 / 2$ & $10 Y R 5 / 4$ & Silt loam & Small blocky & $\begin{array}{l}\text { Moderately medium, } \\
\text { fine and very fine }\end{array}$ & 1.03 & 8 & $5.50 \pm 0.15$ & $4.30 \pm 0.03$ & $1.37 \pm 0.21$ \\
\hline & $\begin{array}{l}\mathrm{Bw} \\
\mathrm{BC}\end{array}$ & $\begin{array}{l}17-42 \\
42-67\end{array}$ & $\begin{array}{l}7.5 \mathrm{YR} 8 / 1 \\
10 \mathrm{YR} 8 / 2\end{array}$ & $\begin{array}{l}10 Y R \text { Y } 5 / 4 \\
10 Y R \text { / } 6 / 4\end{array}$ & $\begin{array}{l}\text { Silt loam } \\
\text { Silt loam }\end{array}$ & $\begin{array}{l}\text { Small blocky } \\
\text { Medium blocky }\end{array}$ & $\begin{array}{l}\text { none } \\
\text { none }\end{array}$ & $\begin{array}{l}1.00 \\
1.63\end{array}$ & $\begin{array}{l}25 \\
15\end{array}$ & $\begin{array}{l}5.86 \pm 0.04 \\
5.90 \pm 0.02\end{array}$ & $\begin{aligned} 4.08 & \pm 0.06 \\
4.00 & \pm 0.1\end{aligned}$ & $\begin{array}{l}1.04 \pm 0.16 \\
0.93 \pm 0.19\end{array}$ \\
\hline \multirow[b]{2}{*}{ 3-month-old } & Ah & $0-20$ & 10YR $5 / 3$ & $10 \mathrm{YR} 2 / 3$ & Clay loam & $\begin{array}{c}\text { Small single } \\
\text { grain }\end{array}$ & $\begin{array}{l}\text { Few medium roots } \\
\text { and many fine roots }\end{array}$ & 1.31 & 5 & $4.96 \pm 0.1$ & $4.00 \pm 0.02$ & $1.50 \pm 0.37$ \\
\hline & $\begin{array}{l}\mathrm{Bw} \\
\mathrm{BC}\end{array}$ & $\begin{array}{c}20-62 \\
62-121\end{array}$ & $\begin{array}{l}10 \text { Y } 7 / 4 \\
75 \text { Y R } 5 / 6\end{array}$ & $\begin{array}{l}10 Y R 4 / 6 \\
5 Y R 3 / 3\end{array}$ & Clay loam & $\begin{array}{l}\text { Big blocky } \\
\text { Small blocky }\end{array}$ & Few fine roots & $\begin{array}{l}1.53 \\
1.63\end{array}$ & $\begin{array}{c}6 \\
90\end{array}$ & $6.00 \pm 0.08$ & $4.38 \pm 0.08$ & $1.09 \pm 0.15$ \\
\hline
\end{tabular}

Notes: values of $\mathrm{pH}\left(\mathrm{H}_{2} \mathrm{O}\right), \mathrm{pH}(\mathrm{KCl})$, and T-N are expressed as mean \pm standard deviation.

\subsection{Soil Total Organic Carbon (TOC) Concentration of Mineral Horizons}

Overall, TOC concentration (Figure 1a) and SOC stocks (Figure 1b) decreased with soil depth. The SOC concentration for the Ah horizon in the control site was significantly greater than the other succession sites, and the 17-year-old site was significantly lower than the other sites for both the Ah and B horizons. There was no significant difference between burned and unburned deep BC horizons. As expected, the rate of decrease of SOC stocks was not as pronounced compared to the SOC concentrations. This is likely due to the higher soil bulk density values for the subsurface horizons compared to the subsurface horizons and thicker subsurface horizons (Table 2). 


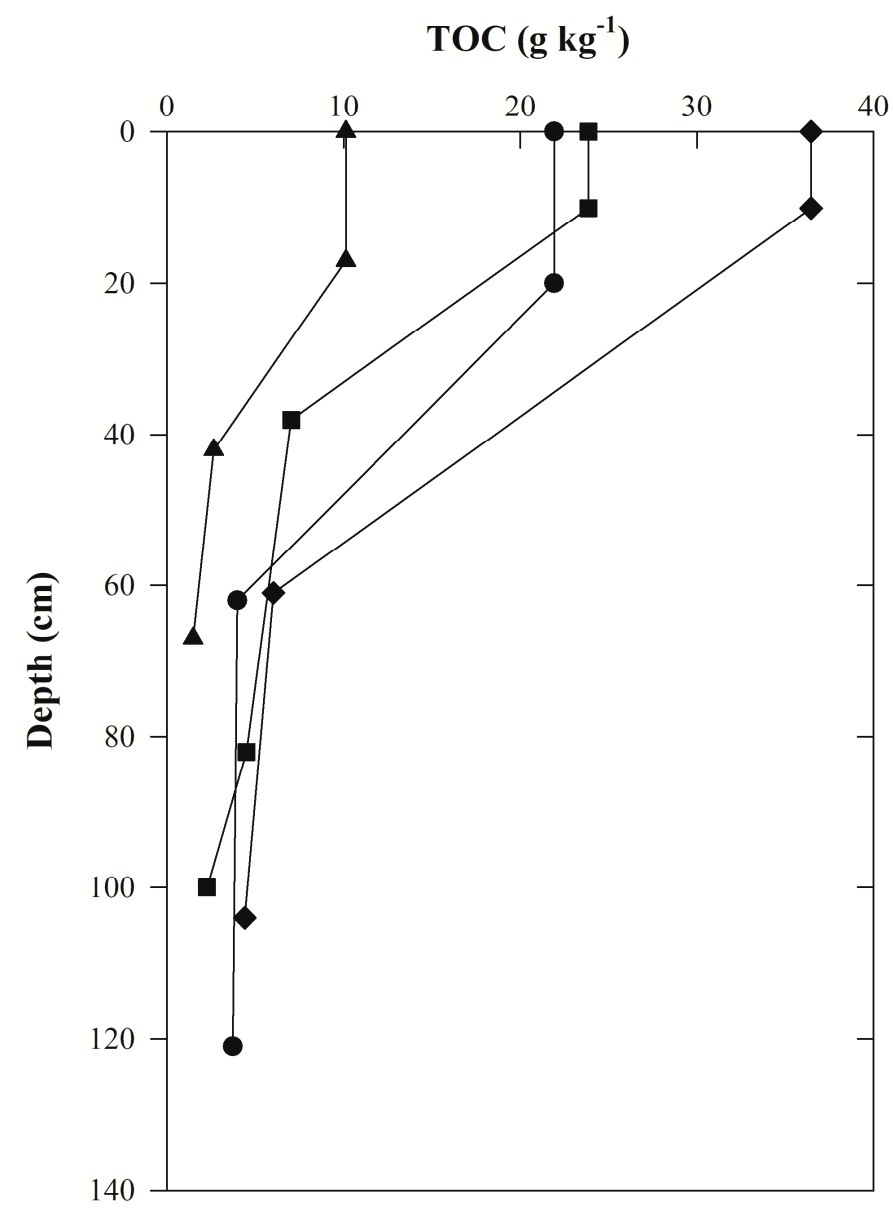

(a)
SOC stocks $\left(\mathrm{Mg} \mathrm{ha}^{-1}\right)$

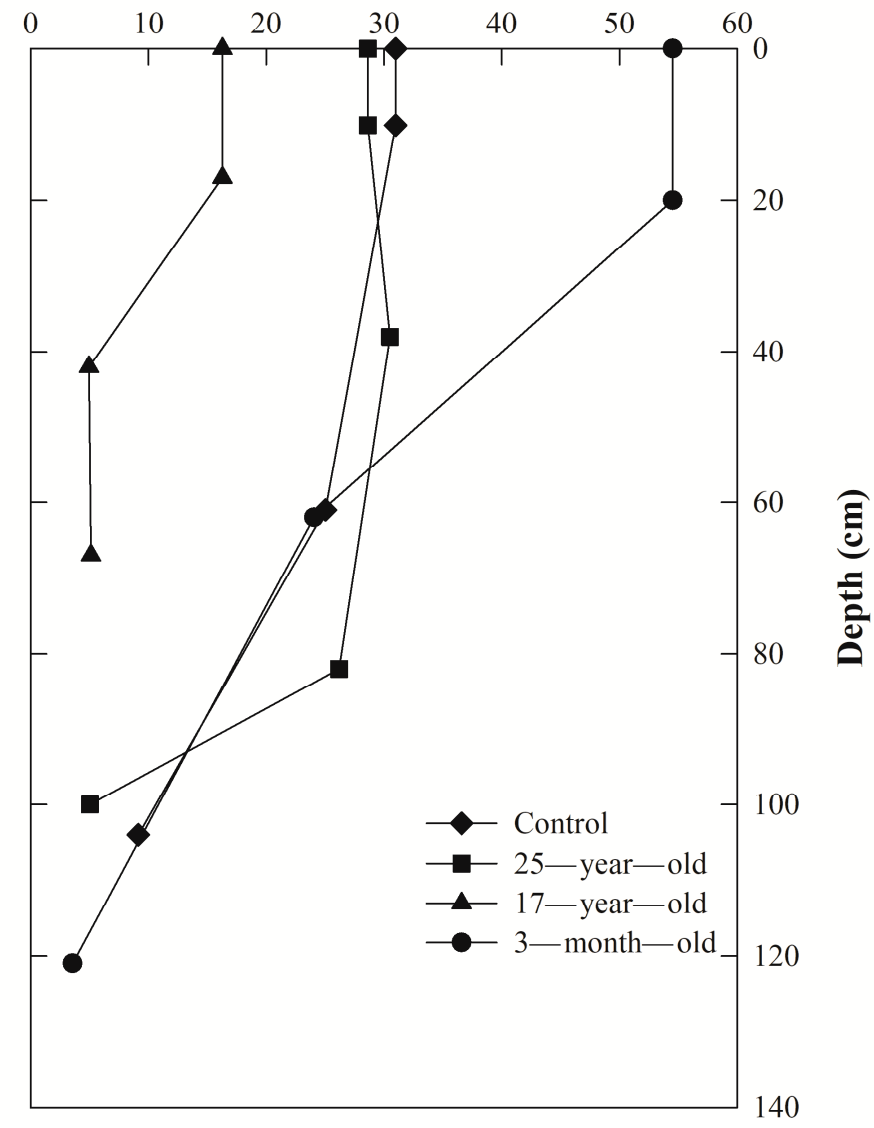

(b)

Figure 1. Changes of soil total organic carbon (TOC) (a) concentration and (b) stocks with depth after a wildfire in mineral horizons.

\subsection{Water Stable Aggregates (WSA) and Associated SOC (WSA-SOC) Concentrations and Stocks}

The variation of WSA showed that the WSA abundance in the A horizon was significantly affected by fire (Figure 2a). The WSA content in different soil horizons was the greatest in the control site, while the 25-year-old site had greater levels than the 17-year-old site. The lowest WSA was found in the A and B horizons of the 3-month-old site. WSA increased with recovery time following fire, but the recovery degree differed among different sites. The abundance of WSA $>2000 \mu \mathrm{m}$ and $250-2000 \mu \mathrm{m}$ in A and B horizons of the 25-year-old site was significantly greater compared to $53-250 \mu \mathrm{m}$ and $<53 \mu \mathrm{m}$ aggregate sizes following a wildfire. However, the opposite was true for the 17-year-old site (Figure 2a).

The greatest concentration of aggregate-associated SOC of the A horizon was in the control site, and the lowest appeared in the 17-year-old site. There was no significant difference in aggregate-associated SOC between the B and BC horizons (Figure 2b). 


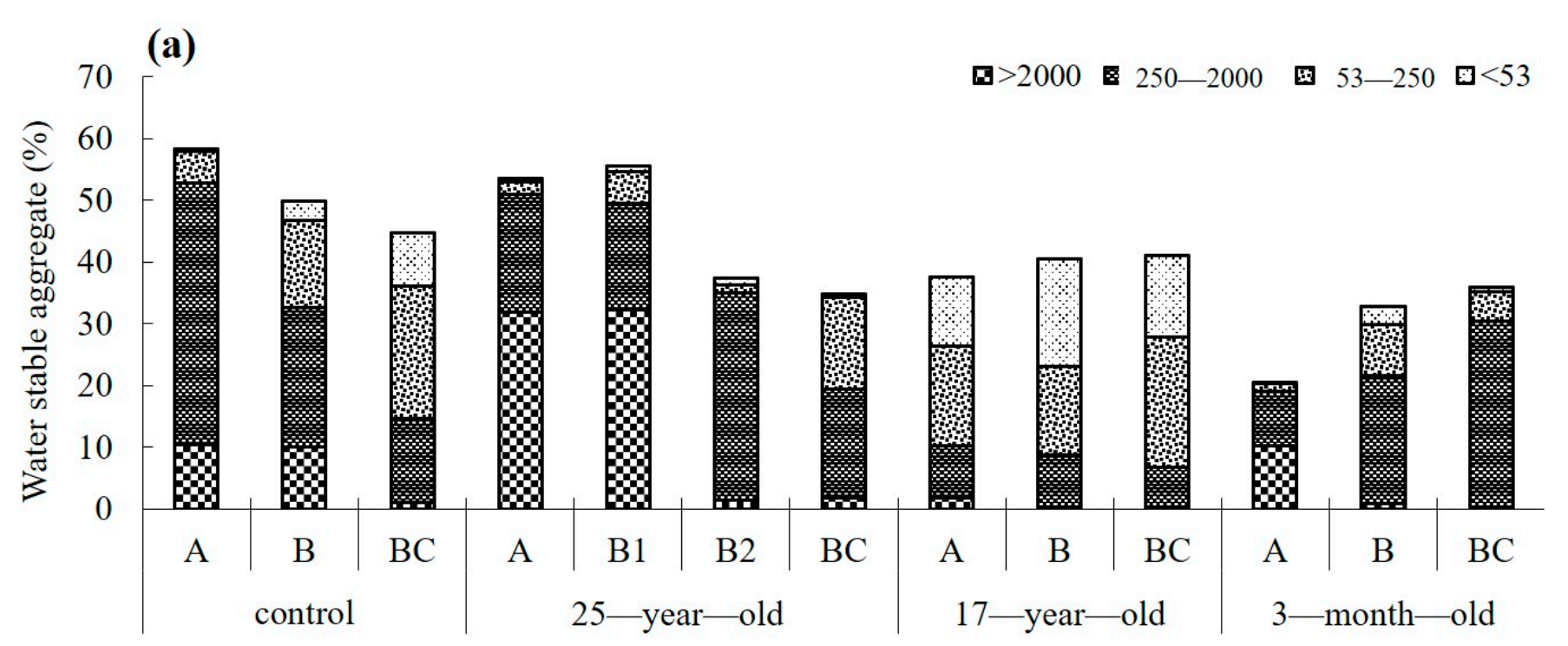

(b)

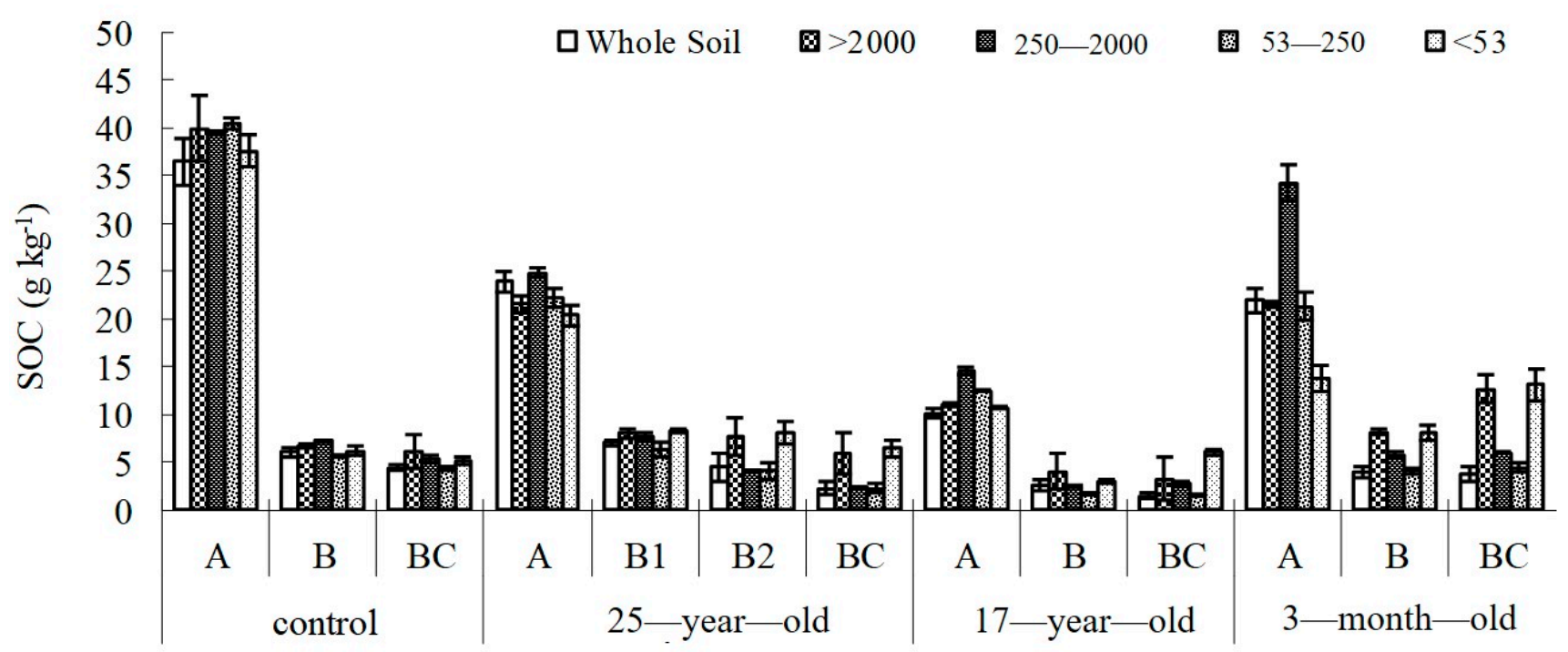

Figure 2. Changes of water stable aggregates (WSA) (a) content and (b) WSA associated SOC (WSA-SOC) concentrations after wildfire. Ranges of $>2000 \mu \mathrm{m}, 250-2000 \mu \mathrm{m}, 53-250 \mu \mathrm{m}$, and $<53 \mu \mathrm{m}$ represent different WSA in size, respectively.

The WSA-SOC stocks of the $>250 \mu \mathrm{m}$ fraction decreased with soil depth (Figure 3). The lowest WSA-SOC stocks of $>2000 \mu \mathrm{m}$ and 250-2000 $\mu \mathrm{m}$ faction was in the 17-year-old site soil. The highest WSA-SOC stocks of $>2000 \mu \mathrm{m}$ and 250-2000 $\mu \mathrm{m}$ fraction in the surface soils occurred in the 25-year-old site and the control site, respectively. The WSA-SOC stocks of the $<250 \mu \mathrm{m}$ fraction first increased and then decreased with soil depth except for the 17 -year-old site. The greatest WSA-SOC stocks of $<250 \mu \mathrm{m}$ fraction in the surface horizon occurred in the 17-year-old site (Figure 3).

\subsection{The Heavy Fraction Soil Organic Carbon (HF-SOC) Concentration and Stocks}

For the Ah and B horizons, both the HF-SOC concentrations (Figure 4a) and stocks (Figure $4 \mathrm{~b}$ ) in the 17-year-old site were significantly lower than the other sites. There was no significant difference in HF-SOC between B and BC horizons for all sites. 


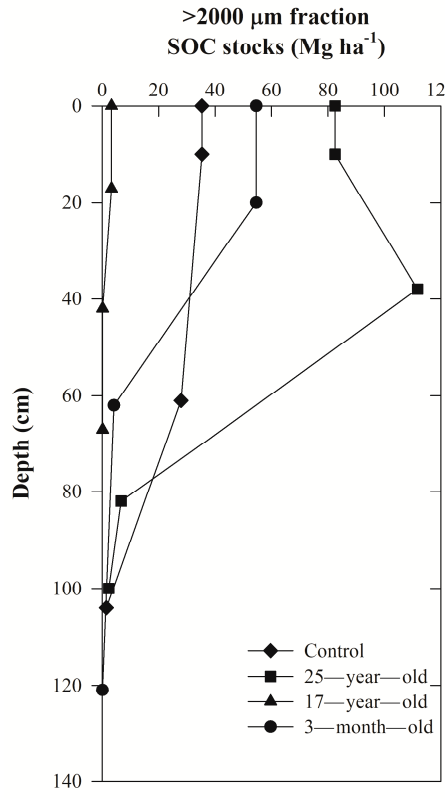

(a)
$250-2000 \mu \mathrm{m}$ fraction SOC stocks (Mg ha $\left.{ }^{-1}\right)$

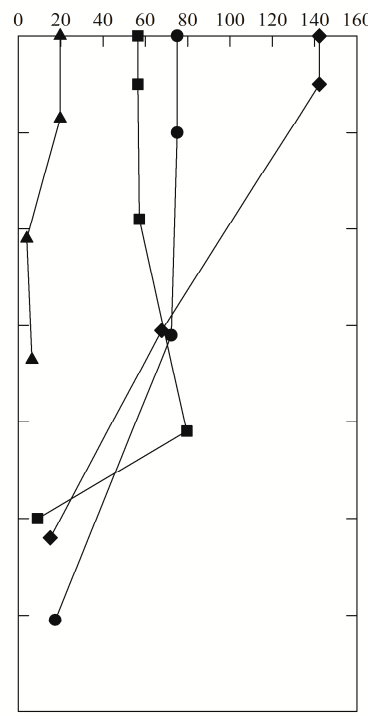

(b)

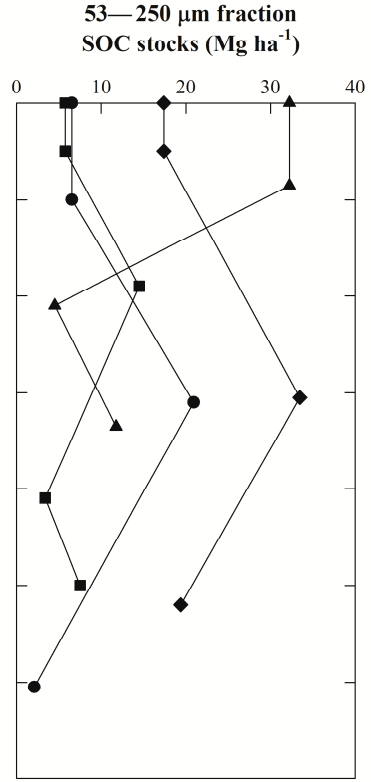

(c)
$<53 \mu \mathrm{m}$ fraction SOC stocks $\left(\mathrm{Mg} \mathrm{ha}^{-1}\right)$

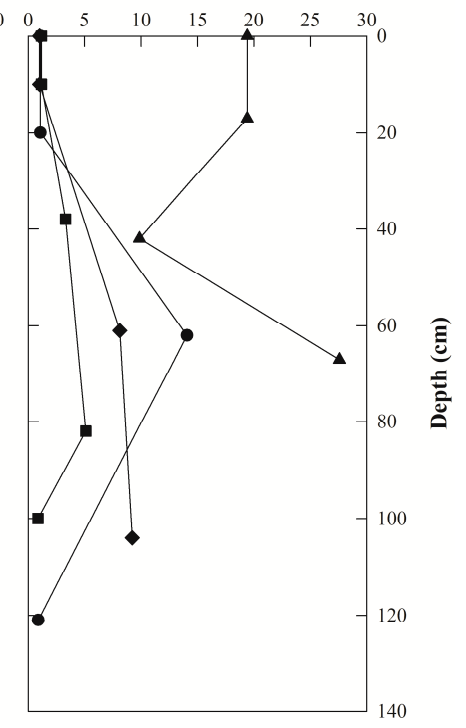

(d)

Figure 3. Changes of water stable aggregates (WSA) associated SOC (WSA-SOC) stocks with depth including (a) $>2000 \mu \mathrm{m}$ fraction, (b) 250-2000 $\mu \mathrm{m}$ fraction, (c) 53-250 $\mu \mathrm{m}$ fraction, and (d) $<53 \mu \mathrm{m}$ fraction after a wildfire in mineral horizons.

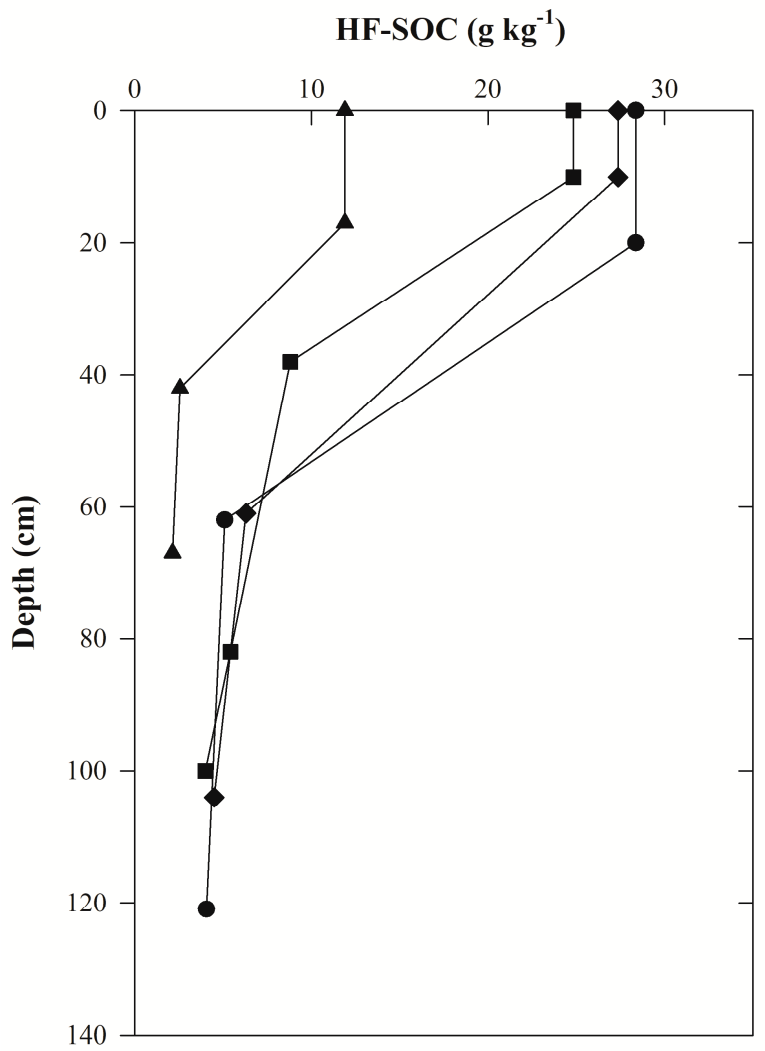

(a)
HF-SOC stocks $\left(\mathrm{Mg} \mathrm{ha}^{-1}\right)$

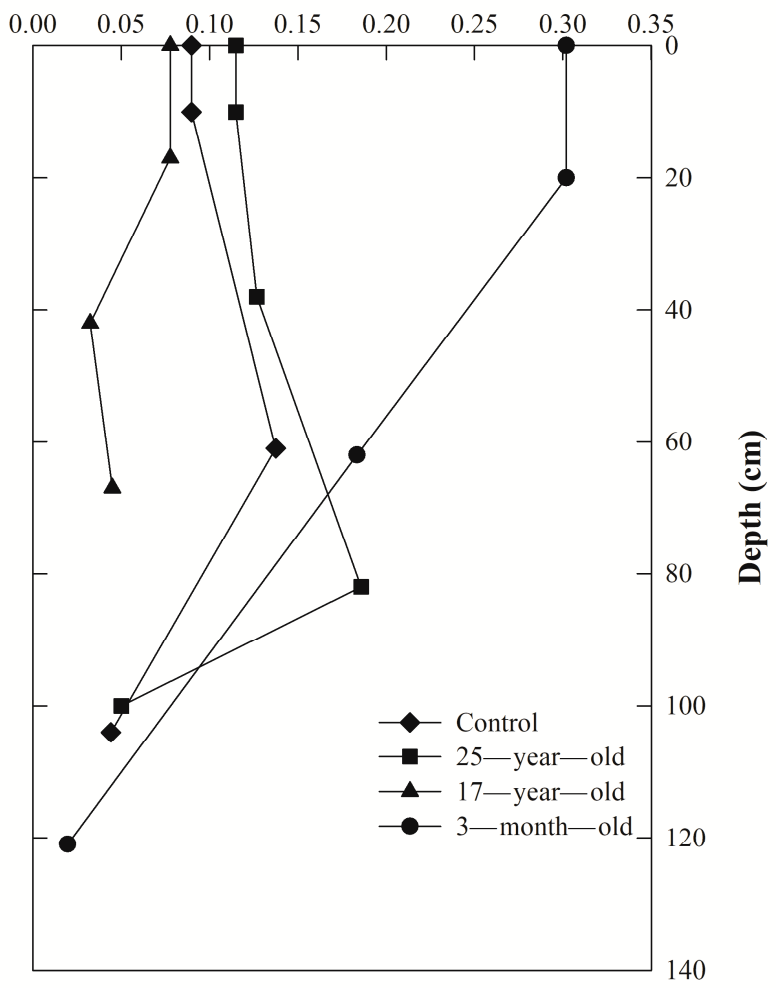

(b)

Figure 4. Changes of soil heavy fractions (HF) organic carbon (HF-SOC) (a) concentration and (b) stocks with depth after a wildfire in mineral horizons. 


\section{Discussion}

\subsection{Variability of Basic Soil Properties after Wildfire}

The direct effect of fires on soil properties included physical changes and indirect effects from habitat changes following wildfires [17]. The plant succession may have had a strong influence on improving soil structure. The SOM consumed by fire initially resulted in the breakdown of the granular structure and the hardening of the surface from rainfall leading to small differences in bulk density values between surface and sub-surface horizons compared to the unburned site. The increase in bulk density often associated with wildfire is due to the destruction and alteration of SOM by heating [44], leading to changes in soil porosity and permeability. The $\mathrm{pH}\left(\mathrm{H}_{2} \mathrm{O}\right)$ and $\mathrm{pH}(\mathrm{KCl})$ of the soil with depth also increased after fire, most likely as the result of released basic cations from the burning of the organic material [45]. Soil organic $\mathrm{N}$ was likely lost immediately upon heating due to volatilization, as found by other workers [44]. Moderate to high-intensity fires convert most soil organic $\mathrm{N}$ to inorganic forms. The 25-year-old site had greater organic $\mathrm{N}$ levels than the 17-year-old site. This may be attributed to the accumulation of N-rich litter and fine root turnover [46], although the rate of recovery in $\mathrm{N}$ decreases with succession from N-rich Populus to N-poor Picea. Fire disturbance had no obvious effect on soil color and texture, but directly destroyed soil structure resulting in decreased soil porosity and increased soil bulk density.

\subsection{Variability of TOC after Wildfire}

Almost all organic layers were burned off by the severe wildfire, according to field investigations. The TOC concentration of soil mineral samples from pedogenic horizons decreased with depth (Figure 1a,b). The TOC concentration of the Ah horizon in the control site was the greatest. SOC was reduced to a small amount of black carbon that was resistant to decomposition under the immediate influence of severe wildfire disturbance, associated with the release of a large amount of carbon dioxide [17]. This likely reduced the overall SOC concentration in the soil. After the wildfire, a large number of herbaceous plants germinated, to be succeeded by the shrubs. Most likely, a succession of vegetation sequences of herbaceous plants was followed by pioneer species invasion after the fire and may have led to a transition of community structure from the original coniferous forest to the broadleaf mixed forest or the broad-leaved forest as observed by others [9]; this likely resulted in litter increase and accumulation. As a result, TOC concentrations increased, for example, at the 25-year-old site, and especially for the topsoil TOC, which was comparable with the TOC levels at the control site. However, in general, TOC did not recover to the levels of the control site in any of the sampling locations. Over time, TOC increased for all sites, but at different rates and levels, as shown by the results at the 25-year-old site compared to the 17-year-old site, especially for the Ah horizon. Nevertheless, because of different site conditions, especially with regard to community succession, the TOC levels at the 17-year-old site will likely not reach that of the 25 -year-old site. TOC concentrations increased over time in species-dominance relay areas at the 25-year-old site due to the growth of invasive broad-leaved forest vegetation, dense canopy, and large amounts of accumulated litter (Table 1). In contrast, self-replacement at the 17-year-old site resulted in decreased TOC levels. Because of the slow rate of self-renewal and the low amount of litter, the TOC accumulated in the soil at slower rates. On the other hand, due to a slower increase of canopy density and a large amount of solar radiation absorbed by the ground surface, the TOC would likely be easily decomposed. Other investigators have made similar observations [47,48]. Species-dominance relay succession at the 25-year-old site led to greater TOC accumulation for the B horizons due to larger above and below-ground biomass associated with the broadleaf trees (Table 2) [49,50].

Initially, the increased soil bulk density and likely decrease of soil hydraulic conductivity in the A horizons (Table 2) reduced leaching and deposition of SOC to the subsurface horizons. For example, even after 17 years of recovery, the TOC content in the B horizon was lower than that of the control site. This was also obvious for the 3-month-old site. 
Over time, the improvement of soil conditions was beneficial for SOC accumulation and stabilization in the B horizon. For example, the presence of clay coatings at the 25-yearold site compared to other sites supports strong pedogenic processes such as leaching of clay-bound organic matter from A to B horizons. Thus, the TOC content for the B horizon was greater at the 25-year-old site compared to the control site. However, there was no difference in the deep BC horizons between different sites. This indicated that the effect of fire on TOC decreases with soil depth, as documented by previous research [43]. However, research has shown that smoldering and slow-burning fires can significantly affect TOC distribution with depth [51,52].

\subsection{Variability of Water Stable Soil Aggregates (WSA) and Associated SOC (WSA-SOC) after Wildfire}

Soil aggregates associated SOC was the main component of soil organic carbon. The content of WSA in different horizons was greater at the control site. In addition, macro-aggregate content $>2.0 \mathrm{~mm}$ in the A horizons did not appear to decrease after fire at the 3-month-old site. This heat-induced aggregation following wildfire has been attributed to the dehydration of soil gels and thermal transformations of the cemented iron and aluminum oxides at temperatures $>220^{\circ} \mathrm{C}$ [53]. A combination of macroaggregate formation after the wildfire [17] with higher associated SOM initially leads to increases of the aggregate associated SOC, especially for the macroaggregates, as observed in our study. As a result, the 3-month-old site had a greater macroaggregate associated SOC than 25-year-old site. However, this part of the organic carbon is not stable due to continued changes of the habitat conditions and smoldering after the fire, which likely could destroy these aggregates. Research has shown that underground fires, especially smoldering of underground biomass, can lead to further losses and destabilization of SOC [6,7].

Overall, the soil aggregate associated SOC in the Ah horizon at fire-affected sites was lower when compared to the control site. The wildfire had partly consumed aggregate associated SOC, which did not recover to the original level along the chronosequence of 25-year-old plant succession. However, leaf litter and roots from broadleaf tree species led to greater soil aggregation compared to coniferous trees. The growth of invasive broadleaved forest vegetation, dense canopy, and large amounts of accumulated litter resulted in greater levels of SOC and likely contributed to the macroaggregates formation at the 25-year-old site and the increased macroaggregate associated SOC. While at the 17-year-old coniferous forest site with a slow rate of self-renewal, a slow increase of canopy density, a low amount of litter, and microbial activity may have led to a decrease of macroaggregates and macroaggregate associated SOC $[54,55]$.

\subsection{Variability of Soil Heavy Fractions (HF) and Associated SOC (HF-SOC) after Wildfire}

The post-fire soil chronosequence was used to examine long-term dynamics of SOC and stable organic carbon (WSA-SOC and HF-SOC) of boreal forests after wildfire at the decadal scale. The HF is composed of invisible organic materials which are tightly bound to soil minerals to form the primary organo-mineral complexes [56,57]. Ashagrie et al. reported that $60-90 \%$ of TOC is in the form of HF-SOC dominating the soil organic carbon pool [56,58-61]. These findings explain the similar trend that HF-SOC and TOC showed for the A horizons. The concentration of the HF-SOC in the A horizons was the greatest in the 3-month-old site, presumably due to the effects on soil gels and thermal transformation of the cemented iron and aluminum oxides [53]. After fire, there was not adequate organic carbon to support the canopy at 17-year-old self-replacement site. Thus organo-mineral complexes were more easily decomposed by exposure to rain, which decreased the HF contents in A and B horizons. In contrast, the HF-SOC increased at the 25-year-old relay succession site due to the increased organic carbon inputs by broadleaf above and below ground biomass. The physical fractions of soil stable organic carbon increased over time at the 25-year-old relay succession sites, where carbon sequestration potential and capacity are larger compared to the 17-year-old self-replacement succession site. 
However, none of the two succession types led to a full recovery of the soil stable carbon contents to the levels of unburned forests. Therefore, the stand-replacing fire can weaken soil carbon sequestration ability. The stable SOC accumulated more in areas where species-dominance relay succession occurred after stand-replacing fires than that in the self-replacement areas. Species-dominance relay succession allowed for invasive broadleaved forest vegetation to establish a dense canopy under which large amounts of litter could accumulate. When self-replacement succession occurred, the canopy density was less compared to species-dominance relay succession, and stable SOC contents decreased over time. The soil carbon sequestration capacity was greater for the species-dominance relay succession.

\section{Conclusions}

Past soil color and texture change little following the wildfire, while soil structure degraded significantly leading to decreased soil porosity and increased soil bulk density. The soil under species-dominance relay succession showed a greater carbon sequestration capacity and potential. At the decadal scale, the TOC and stable SOC (WSA and HF) could not recover to the levels of the control site in any area due to stand-replacing fire. SOC and stable SOC increased over time in species-dominance relay areas, while self-replacement ones showed the opposite results. WSA-SOC increased over time following fire, but the recovery rate differed among sites. Changes in physical and biochemical characteristics of organic inputs, re-vegetation, and canopy after wildfire were responsible for the observed SOC differences and dynamics. The ability of soil to sequester carbon decreased after wildfire disturbances. These disturbances were more pronounced for surface soil horizons. This study provides a quantitative assessment of SOC changes after wildfires that are useful for forest management and modeling forecasts of SOC stocks, especially in boreal forests. However, our study was limited to a boreal forest ecosystem, and studies on other forest ecosystems are needed.

Author Contributions: Conceptualization, Z.-X.S., Q.-B.W. and C.-L.H.; methodology, C.-L.H., Z.X.S., Q.-B.W. and P.R.O.; software, Z.-X.S. and S.S.; validation, Z.-X.S., C.-L.H., S.S. and P.R.O.; formal analysis, Z.-X.S., S.S. and Z.L.; investigation, C.-L.H., Z.-X.S., Q.-B.W. and S.S.; resources, Z.-X.S., C.-L.H. and Q.-B.W.; data curation, Z.-X.S.; writing-original draft preparation, Z.-X.S., C.-L.H. and S.S.; writing-review and editing, Z.-X.S., C.-L.H., Q.-B.W., Z.L. and P.R.O.; visualization, C.-L.H., Z.-X.S. and Q.-B.W.; supervision, Z.-X.S. and Q.-B.W.; project administration, C.-L.H., Z.-X.S. and Q.-B.W.; funding acquisition, C.-L.H., Z.-X.S. and Q.-B.W. All authors have read and agreed to the published version of the manuscript.

Funding: This research was funded by grants from the National Basic Research Program (973 Program, 2011CB403206) and National Natural Science Foundation of China (No. 41171172, 41807002, and 41771245).

Acknowledgments: The authors sincerely thank all the students and staff who provided their input to this study. This research was supported by the National Key Basic Research Development Program (973 Program, 2011CB403206) and the National Natural Science Foundation of China (No. 41171172, 41807002 , and 41771245). Our acknowledgments are also extended to the anonymous reviewers for their constructive reviews of the manuscript. Zamir Libohova is a member of the research consortium GLADSOILMAP supported by the Loire Valley Institute for Advanced Research Studies (France).

Conflicts of Interest: The authors declare no conflict of interest. The funders had no role in the design of the study; in the collection, analyses, or interpretation of data; in the writing of the manuscript, or in the decision to publish the results.

\section{References}

1. Christensen, S. Decomposability of recalcitrant soil carbon assessed by denitrification. FEMS Microbiol. Lett. 1992, 86, 267-274. [CrossRef]

2. Hassink, J.; Whitmore, A.P.; Kubát, J. Size and density fractionation of soil organic matter and the physical capacity of soils to protect organic matter. Eur. J. Agron. 1997, 7, 189-199. [CrossRef]

3. Amundson, R. The carbon budget in soils. Annu. Rev. Earth Planet. Sci. 2001, 29, 535-562. [CrossRef] 
4. Pregitzer, K.S.; Euskirchen, E.S. Carbon cycling and storage in world forests: Biome patterns related to forest age. Glob. Chang. Biol. 2004, 10, 2052-2077. [CrossRef]

5. Ziegler, S.E.; Sharon, A.; Billings, S.A.; Chad, S.; Lane, C.S.; Li, J.W.; Fogel, M.L. Warming alters routing of labile and slowerturnover carbon through distinct microbial groups in boreal forest organic soils. Soil Biol. Biochem. 2013, 60, 23-32. [CrossRef]

6. Rein, G. Smouldering fires and natural fuels. In Fire Phenomena in the Earth System-An Interdisciplinary Approach to Fire Science; Belcher, C., Ed.; Wiley and Sons: Hoboken, NJ, USA, 2013; Chapter 2. Available online: http:/ / onlinelibrary.wiley.com/doi/10.1 002/9781118529539.ch2 (accessed on 7 September 2021).

7. Rein, G.; Huang, X. Smouldering wildfires in peatlands, forests and the arctic: Challenges and perspectives. Curr. Opin. Environ. Sci. Health 2021, 24, 100296. [CrossRef]

8. Bouchard, M.; Pothier, D. Long-term influence of fire and harvesting on boreal forest age structure and forest composition in eastern Québec. For. Ecol. Manag. 2011, 261, 811-820. [CrossRef]

9. Chen, H.Y.H.; Vasiliauskas, S.; Kayahara, G.J.; Ilisson, T. Wildfire promotes broadleaves and species mixture in boreal forest. For. Ecol. Manag. 2009, 257, 343-350. [CrossRef]

10. Wang, X.; He, H.S.; Li, X. The long-term effects of fire suppression and reforestation on a forest landscape in Northeastern China after a catastrophic wildfire. Landsc. Urban Plan. 2007, 79, 84-95. [CrossRef]

11. Kawahigashi, H.; Kasuga, S.; Ando, T.; Kanamori, H.; Wu, J.; Yonemaru, J.I.; Sazuka, T.; Matsumoto, T. Positional cloning of ds1, the target leaf spot resistance gene against Bipolaris sorghicola in sorghum. Theor. Appl. Genet. 2011, 123, 131-142. [CrossRef]

12. Cai, W.; Yang, J.; Liu, Z.; Hu, Y.; Weisberg, P.J. Post-fire tree recruitment of a boreal larch forest in Northeast China. For. Ecol. Manag. 2013, 307, 20-29. [CrossRef]

13. Certini, G. Effects of fire on properties of forest soils: A review. Oecologia 2005, 143, 1-10. [CrossRef]

14. Chen, F.S.; Zeng, D.H.; Fahey, T.J.; Liao, P.F. Organic carbon in soil physical fractions under different-aged plantations of Mongolian pine in semi-arid region of Northeast China. Appl. Soil Ecol. 2010, 44, 42-48. [CrossRef]

15. Magnani, F.; Mencuccini, M.; Borghetti, M.; Berbigier, P.; Berninger, F.; Delzon, S.; Grelle, A.; Hari, P.; Jarvis, P.G.; Kolari, P.; et al. The human footprint in the carbon cycle of temperate and boreal forests. Nature 2007, 447, 849-851. [CrossRef]

16. Amiro, B.D.; Orchansky, A.L.; Barr, A.G.; Black, T.A.; Chambers, S.D.; Chapin Lii, F.S.; Goulden, M.L.; Litvak, M.; Liu, H.P.; McCaughey, J.H.; et al. The effect of post-fire stand age on the boreal forest energy balance. Agric. For. Meteorol. 2006, 140, 41-50. [CrossRef]

17. Chen, H.Y.H.; Shrestha, B.M. Stand age, fire and clearcutting affect soil organic carbon and aggregation of mineral soils in boreal forests. Soil Biol. Biochem. 2012, 50, 149-157. [CrossRef]

18. Elliott, E.T. Aggregate structure and carbon, nitrogen, and phosphorus in native and cultivated soils. Soil Sci. Soc. Am. J. 1986, 50, 627-633. [CrossRef]

19. Jastrow, J.D. Soil aggregate formation and the accrual of particulate and mineral-associated organic matter. Soil Biol. Biochem. 1996, 28, 665-676. [CrossRef]

20. Vance, E.D. Agricultural site productivity: Principles derived from long-term experiments and their implications for intensively managed forests. For. Ecol. Manag. 2000, 138, 369-396. [CrossRef]

21. Shrestha, B.M.; Singh, B.R.; Sitaula, B.K.; Lal, R.; Bajracharya, R.M. Soil aggregate- and particle-associated organic carbon under different land uses in Nepal. Soil Sci. Soc. Am. J. 2007, 71, 1194-1203. [CrossRef]

22. Burri, K.; Graf, F.; Böll, A. Revegetation measures improve soil aggregate stability: A case study of a landslide area in Central Switzerland. For. Snow Landsc. Res. 2009, 82, 45-60.

23. Wilson, G.W.T.; Rice, C.W.; Rillig, M.C.; Springer, A.; Hartnett, D.C. Soil aggregation and carbon sequestration are tightly correlated with the abundance of arbuscular mycorrhizal fungi: Results from long-term field experiments. Ecol. Lett. 2009, 12, 452-461. [CrossRef]

24. Mataix-Solera, J.; Cerdà, A.; Arcenegui, V.; Jordán, A.; Zavala, L.M. Fire effects on soil aggregation: A review. Earth-Sci. Rev. 2011, 109, 44-60. [CrossRef]

25. Varela, M.E.; Benito, E.; Keizer, J.J. Effects of wildfire and laboratory heating on soil aggregate stability of pine forests in Galicia: The role of lithology, soil organic matter content and water repellency. Catena 2010, 83, 127-134. [CrossRef]

26. Cambardella, C.A.; Elliott, E.T. Carbon and nitrogen distribution in aggregates from cultivated and native grassland soils. Soil Sci. Soc. Am. J. 1993, 57, 1071-1076. [CrossRef]

27. Nascente, A.S.; Li, Y.C.; Crusciol, C.A.C. Cover crops and no-till effects on physical fractions of soil organic matter. Soil Tillage Res. 2013, 130, 52-57. [CrossRef]

28. Hassink, J. Density fractions of soil macroorganic matter and microbial biomass as predictors of C and N mineralization. Soil Biol. Biochem. 1995, 27, 1099-1108. [CrossRef]

29. Wander, M.M.; Traina, S.J. Organic matter fractions from organically and conventionally managed soils: I. Carbon and nitrogen distribution. Soil Sci. Soc. Am. J. 1996, 60, 1081-1087. [CrossRef]

30. Golchin, A.; Clarke, P.; Oades, J.M.; Skjemstad, J.O. The effects of cultivation on the composition of organic matter and structural stability of soils. Aust. J. Soil Res. 1995, 33, 975-993. [CrossRef]

31. Barrios, E.; Buresh, R.J.; Sprent, J.I. Nitrogen mineralization in density fractions of soil organic matter from maize and legume cropping systems. Soil Biol. Biochem. 1996, 28, 1459-1465. [CrossRef] 
32. Alvarez, R.; Alvarez, C.R. Soil organic matter pools and their associations with carbon mineralization kinetics. Soil Sci. Soc. Am. J. 2000, 64, 184-189. [CrossRef]

33. Yu, C.L.; Zhang, H.; Yang, X.Q. Analysis of characteristics of forest fires in the Great Xing'an mountains, China. Heilongjiang Meteorol. 2007, 4, 28-29, 34.

34. Chinese Soil Taxonomy Research Group, Institute of Soil Science Chinese Academy of Sciences, and Cooperative Research Group on Chinese Soil Taxonomy. Keys to Chinese Soil Taxonomy; University of Science and Technology of China Press: Hefei, China, 2001.

35. IUSS Working Group WRB. World reference base for soil resources 2014, update 2015 international soil classification system for naming soils and creating legends for soil maps. In World Soil Resources Reports No. 106; FAO: Rome, Italy, 2015.

36. Soil Survey Staff. Keys to Soil Taxonomy, 12th ed.; NRCS U.S. Gov. Print. Office: Washington, DC, USA, 2014.

37. Yu, W.Y.; Zhou, G.S.; Zhao, X.L.; Xie, Y.B.; Jia, Q.Y. Forest fire characteristics and impact factors in the Great Xing'an mountains, China. J. Meteorol. Environ. 2009, 4, 1-5.

38. Meira Castro, A.C.; Nunes, A.; Sousa, A.; Lourenço, L. Mapping the causes of forest fires in portugal by clustering analysis. Geosciences 2020, 10, 53. [CrossRef]

39. Veraverbeke, S.; Lhermitte, S.; Verstraeten, W.W.; Goossens, R.A. A time-integrated MODIS burn severity assessment using the multi-temporal differenced normalized burn ratio (dNBRMT). Int. J. Appl. Earth Obs. Geoinf. 2011, 13, 52-58. [CrossRef]

40. Schoeneberger, P.J.; Wysocki, D.A.; Benham, E.C. Soil-survey-staff. In Field Book for Describing and Sampling Soils Version 3.0; Natural Soil Survey Center: Lincoln, NE, USA, 2012.

41. Yoder, R.E. A direct method of aggregate analysis of soils and a study of the physical nature of erosion losses. Agron. J. 1936, 28, 337-351. [CrossRef]

42. Gregorich, E.G.; Ellert, B.H. Light fraction and macro-organic matter in mineral soils. In Soil Sampling and Methods of Analysis Boca Raton; Carter, M.R., Ed.; Lewis Publisher: Boca Raton, FL, USA, 1993; pp. 397-408.

43. Wang, J.; Song, C.; Wang, X.; Song, Y. Changes in labile soil organic carbon fractions in wetland ecosystems along a latitudinal gradient in Northeast China. Catena 2012, 96, 83-89. [CrossRef]

44. DeBano, L.F.; Raymond, M.R.; Conrad, C.E. Soil Heating in Chaparral Fires Effects on Soil Properties, Plant Nutrients, Erosion, and Runoff; Pacific Southwest Forest and Range Experiment Station: Berkeley, CA, USA, 1979; p. 21.

45. Simard, D.G.; Fyles, J.W.; Paré, D.; Nguyen, T. Impacts of clearcut harvesting and wildfire on soil nutrient status in the Quebec boreal forest. Can. J. Soil Sci. 2001, 81, 229-237. [CrossRef]

46. Laganière, J.; Angers, A.D.; Paré, D. Carbon accumulation in agricultural soils after afforestation: A meta-analysis. Glob. Chang. Biol. 2010, 16, 439-453. [CrossRef]

47. Finér, L.; Messier, C.; DeGrandpré, L. Fine-root dynamics in mixed boreal conifer-broad-leafed forest stands at different successional stages after fire. Can. J. For. Res. 1997, 27, 304-314. [CrossRef]

48. Yuan, Z.Y.; Chen, H.Y.H. Fine root biomass, production, turnover rates, and nutrient contents in boreal forest ecosystems in relation to species, climate, fertility, and stand age: Literature review and meta-analyses. Crit. Rev. Plant Sci. 2010, $29,204-221$. [CrossRef]

49. Ruess, R.W.; Van Cleve, K.; Yarie, J.; Viereck, L.A. Contributions of fine root production and turnover to the carbon and nitrogen cycling in taiga forests of the Alaskan interior. Can. J. For. Res. 1996, 26, 1326-1336. [CrossRef]

50. Ruess, R.W.; Hendrick, R.L.; Burton, A.J.; Pregitzer, K.S.; Sveinbjornsson, B.; Allen, M.F.; Maurer, G.E. Coupling fine root dynamics with ecosystem carbon cycling in black spruce forests of interior Alaska. Ecol. Monogr. 2003, 73, 643-662. [CrossRef]

51. McCarty, J.L.; Smith, T.E.L.; Turetsky, M.R. Arctic fires re-emerging. Nat. Geosci. 2020, 13, 658-660. [CrossRef]

52. Scholten, R.C.; Jandt, R.; Miller, E.A.; Rogers, B.M.; Veraverbeke, S. Overwintering fires in boreal forests. Nature 2021, 593, 399-404. [CrossRef]

53. Giovannini, G.; Lucchesi, S.; Giachetti, M. Beneficial and detrimental effects of heating on soil quality. In Fire in Ecosystem Dynamics; Goldammer, M.J.G., Jenkins, M.J., Eds.; SPB Academic Publishing: The Hague, The Netherlands, $1990 ;$ pp. 95-102.

54. Liao, J.D.; Boutton, T.W. Soil microbial biomass response to woody plant invasion of grassland. Soil Biol. Biochem. 2008, 40, 1207-1216. [CrossRef]

55. Abiven, S.; Menasseri, S.; Chenu, C. The effects of organic inputs over time on soil aggregate stability-A literature analysis. Soil Biol. Biochem. 2009, 41, 1-12. [CrossRef]

56. Christensen, B.T. Organic Matter in Soil: Structure, Function and Turnover, Dias Report, Tjele; Danish Institute of Agricultural Sciences, Research Center Foulum: Tjele, Denmark, 2000; p. 95.

57. Sohi, S.P.; Mahieu, N.; Arah, J.R.M.; Powlson, D.S.; Madari, B.; Gaunt, J.L. A procedure for isolating soil organic matter fractions suitable for modeling. Soil Sci. Soc. Am. J. 2001, 65, 1121-1128. [CrossRef]

58. Ashagrie, Y.; Zech, W.; Guggenberger, G.; Mamo, T. Soil aggregation, and total and particulate organic matter following conversion of native forests to continuous cultivation in Ethiopia. Soil Tillage Res. 2007, 94, 101-108. [CrossRef]

59. Roscoe, R.; Buurman, P. Tillage effects on soi1 organic matter in density fiactions of a Cerrado oxisol. Soil Tillage Res. 2003, 70, 107-109. [CrossRef]

60. Roscoe, R.; Buurman, P.; Velthorst, E.J.; Vasconcellos, C.A. Soil organic matter dynamics in density and particle-size fractions as revealed by the ${ }^{13} \mathrm{C} /{ }^{12} \mathrm{C}$ isotopic ratio in a Cerrado's oxisol. Geoderma 2001, 104, 185-202. [CrossRef]

61. de Moraes Sa, J.C.; Lal, R. Stratification ratio of soil organic matter pools as an indicator of carbon sequestration in a tillage chronosequence on a Brazilian Oxisol. Soil Tillage Res. 2009, 103, 46-56. 